\title{
Kemampuan Literasi Melalui Pengembangan Soal pada Materi
} Statistika

\author{
Astri Oktaviranda ${ }^{1 *)}$, \& Adi Asmara ${ }^{2}$ \\ ${ }^{1,2}$ Universitas Muhammadiyah Bengkulu, Bengkulu, Indonesia
}

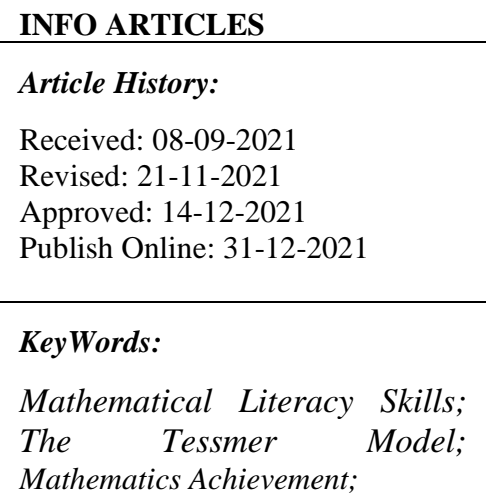

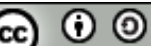

(C) under a Creative Commons AttributionShareAlike 4.0 International License.

\begin{abstract}
Students in Indonesia, the achievement of international mathematics achievement is still low. This can be seen from the results of the PISA study in 2018 to solve PISA characteristic bar questions. Therefore, it is necessary to develop questions to train students' mathematical literacy skills, one of which is using statistical material. The purpose of this research is to develop valid and practical mathematical literacy skills questions for statistical materials. This research is development research with the Tessmer model. The subjects in this study were 30 class VIII students of SMP 58 North Bengkulu in the 2020/2021 academic year. The data collection techniques in this study were: 1) data collection methods, namely interviews. 2) data collection instruments, namely documents, question validation sheets, comments or suggestions sheets, and prototypes. The data analysis technique used is qualitative analysis technique. This study resulted in 10 valid and practical questions
\end{abstract}

\begin{abstract}
Abstrak: Siswa di Indonesia pencapaian prestasi matematika secara internasional masih rendah. Hal tersebut dapat dilihat dari hasil studi PISA pada tahun 2018. Untuk menyelesaikan soal berkarakteristik PISA. Maka diperlukannya pengembangan soal untuk melatih kemampuan literasi matematis siswa yang salah satunya menggunakan materi statistika. Tujuan penelitian ini adalah mengembangkan soal-soal kemampuan literasi matematis materi statistika yang valid dan praktis. Jenis penelitian yang digunakan yaitu penelitian pengembangan (Development Research) dengan model Tessmer. Subjek uji coba dalam penelitian ini adalah 30 siswa kelasVIII SMP 58 Bengkulu Utara tahun ajaran 2020/2021 Teknik penelitian yaitu: 1) metode pengumpulan data, yaitu wawancara. 2) instrument pengumpulan data yaitu dokumen, lembar validasi soal, lembar komentar atau saran, dan prototype. Teknik analisis data yang digunakan yaitu teknik analisis kualitatif. Simpulan penelitian menghasilkan 10 butir soal yang valid dan praktis
\end{abstract}

\footnotetext{
Correspondence Address: Jln. Bali, Kp. Bali, Kec. Tlk. Segara, Kota Bengkulu, Bengkulu, Indonesia, Kode Pos 38119; e-mail: astrioktavirandaaci17@gmail.com

How to Cite (APA $6^{\text {th }}$ Style): Oktaviranda, A., \& Asmara, A. (2021). Kemampuan Literasi Melalui Pengembangan Soal pada Materi Statistika. JKPM (Jurnal Kajian Pendidikan Matematika), 7(1): 15-26. http://dx.doi.org/10.30998/jkpm.v7i1.10620
}

\section{Copyright: 2021 Astri Oktaviranda, Adi Asmara}

Competing Interests Disclosures: The authors declare that they have no significant competing financial, professional or personal interests that might have influenced the performance or presentation of the work described in this manuscript. 


\section{PENDAHULUAN}

Matematika merupakan ilmu dasar yang memegang peranan penting dalam pengembangan sains dan teknologi, karena matematika digunakan sebagai sarana berfikir untuk menumbuh kembangkan daya nalar, cara berfikir logis, sistematis, dan kritis (Hobri, 2008). Hal ini dapat dikatakan bahwa matematika merupakan salah satu mata pelajaran yang memiliki kontribusi besar dalam kehidupan manusia (Khotimah, 2018). Di sisi lain, matematika adalah suatu cara untuk menemukan jawaban terhadap masalah yang dihadapi manusia, suatu cara menggunakan informasi, menggunakan pengetahuan tentang menghitung dan yang paling penting adalah memikirkan dalam diri manusia itu dalam melihat dan menggunakan hubunganhubungan, sehingga dapat diartikan bahwa dengan belajar matematika kita dapat menemukan jawaban atas masalah yang sedang dihadapi yang berhubungan dengan matematika (Abdurrahman, 2003:252). Selain itu, matematika memiliki tujuan pembelajaran yakni dapat diterapkannya didalam kehidupan sehari-hari dan di dalam ilmu pengetahuan lainnya dengan tepat, demi terbentuknya sumber daya manusia yang berkualitas (Rodiawati \& Komarudin, 2018). Oleh sebab itu, sarana untuk memecahkan masalah dalam kehidupan sehari-hari semua orang harus mempelajari matematika (Wiratomo \& Mulyatna, 2020). Sejalan dengan hal tersebut, mengacu pada National Council of Teachers Mathematics tujuan diberikannya mata pelajaran matematika supaya lima kompetensi dimiliki siswa, yaitu: pemecahan masalah matematis (mathematical problem solving), komunikasi matematis (mathematical communication), penalaran matematis (mathematical reasoning), koneksi matematis (mathematical connection), dan representasi matematis (mathematical representation) kemampuan ke lima hal tersebut merupakan kemampuan literasi matematis (Maryanti, 2012).

Kata literasi merupakan kata serapan dari bahasa Inggris literacy yang artinya berdasarkan kamus bahasa Inggris yaitu kemampuan membaca dan menulis, orang dapat dikatakan literat apabila dia mampu membaca dan menulis (Abidin et. al., 2018). Literasi dapat diartikan sebagai kemampuan siswa untuk membaca tidak hanya buku teks, namun berbagai fenomena dalam kehidupan sehari-hari sebagai lingkungan belajar secara analitis, kritis, dan reflektif yang artinya bahwa literasi tidak hanya hal membaca buku teks tetapi juga membaca berbagai fenomena dalam kehidupan sehari-hari (Asmara \& Risnanosanti, 2019). Kemampuan literasi matematis merupakan suatu kemampuan individu untuk merumuskan, menggunakan, dan menafsirkan matematika dalam berbagai konteks. Termasuk kemampuan melakukan penalaran secara matematis dan menggunakan konsep, prosedur, fakta untuk menggambarkan, menjelaskan atau memperkirakan fenomena/kejadian (Kuswidi, 2017). Penilaian kemampuan siswa dalam literasi secara internasional dilaksanakan oleh Organisation For Economic Cooperation and Development (OECD) menyelenggarakan studi tentang program penilaian siswa tingkat internasional yang dinamakan PISA (Program For International Student Assessment) terhadap keterampilan dan kemampuan siswa usia 15 tahun (OECD, 2019). Usia 15 tahun merupakan usia di mana siswa di sebagian besar negara mendekati akhir dari wajib belajar (Stacey, 2011). Keterampilan dan kemampuan dalam PISA yang dinilai meliputi matematika, membaca, dan sains (OECD, 2019). Literasi matematis sangat berperan penting dalam kehidupan sehari-hari. Dengan melalui PISA tersebut kemampuan literasi matematis siswa dapat dinilai melalui skala internasional. Namun Pentingnya literasi matematika ini, ternyata belum sejalan dengan prestasi siswa Indonesia di mata Internasional. Indonesia dalam taraf internasional dipandang belum mampu melahirkan generasi yang berliterasi (Khanifah et. al., 2019).

Penyelenggaraan PISA dilakukan tiap 3 tahun sekali, yaitu dari tahun 2000, 2003, 2006, hingga tahun 2018 (Shiel, dkk., 2007). Indonesia berpartisipasi sejak awal dalam penyelenggaraan PISA. Peringkat Indonesia dalam PISA masing sangat rendah. Hal ini dapat dilihat dari hasil PISA Indonesia bidang matematika tahun 2018 skor yang didapat hanya 379 dan menduduki peringkat 72 dari 78 negara yang berpartisipasi (Asmara \& Sari, 2021). Hampir 80\% siswa Indonesia hanya mampu mencapai di bawah garis 
batas level 2 dari enam level yang diujikan (Lutfianto et. al., 2013). Mengacu pada penilaian PISA, literasi matematika siswa di Indonesia berdasarkan studi internasional masih belum memuaskan (Fathani dalam Habibi \& Suparman, 2020). Lebih lanjut, instrumen dalam pengukuran literasi juga menjadi masalah tersendiri. Dari hasil penilaian PISA bidang matematika yang rendah tentunya disebabkan oleh beberapa faktor. Salah satu faktor dari rendahnya hasil studi PISA di Indonesia yaitu kurang ketersediaan soal-soal yang dapat melatih kemampuan literasi matematis siswa yang diungkapkan oleh Wardhani dan Rumianti dalam (Kemdikbud, 2011), hal ini didukung dari (Junika et. al., 2020). Faktor lain dari rendahnya hasil studi PISA di Indonesia yaitu siswa kurang terlatih menyelesaikan soal berkarakteristik seperti soal PISA. Artinya siswa terbiasa mengerjakan soal-soal yang sesuai dengan contoh yang diberikan oleh pendidik. Hal ini membuat siswa Indonesia pada umumnya masih kurang terlatih menyelesaikan soal yang berindikator kemampuan literasi matematis. Sehingga kemampuan literasi siswa perlu lebih dioptimalkan, disarankan agar pendidik lebih dibiasakan memberikan soal model PISA (Sasongko et. al., 2016). Dari permasalahan di atas maka diperlukan pengembangan soal yang dapat melatih siswa dalam mengerjakan soal literasi matematika yang sesuai kondisi di Indonesia (Mahfudhoh, et. al., 2017).

Lebih lanjut dalam perspektif materi, di Indonesia, konten data disebut dengan materi statistika. Materi statistika merupakan materi yang dipelajari di kelas VIII. Namun literasi statistika di SMP siswa masih mengalami kesulitan dalam menganalisis data maupun membaca data berupa diagram, tabel dan grafik. Selain itu materi yang sulit bagi siswa yaitu ukuran pemusatan data mean/rata-rata hitung bahkan dalam menentukan median/nilai tengah siswa masih salah langkah dalam menentukan dan mengerjakannya. Kemampuan literasi statistika yang sulit bagi siswa adalah komponen mengevaluasi, sehingga literasi matematis materi statistika perlu dikembangkan.

Berdasarkan observasi yang sudah dilakukan di Sekolah Menengah Pertama, bahwa guru sudah menerapkan kemampuan literasi matematis ke siswa. Namun kemampuan literasi matematis siswa perlu ditingkatkan lagi. Faktor diantaranya adalah kesulitan yang dialami oleh siswa ketika menyelesaikan soal kemampuan literasi matematis. Siswa lebih terbiasa mengerjakan soal yang tidak jauh dari contoh atau penyelesaian yang langsung dapat diselesaikan. Masalah yang dihadapi oleh guru adalah kurang tersedianya soal-soal yang didesain khusus yang sesuai dengan potensi siswa dan karakter siswa sehingga diasumsikan bahwa potensi siswa menggunakan penalaran (reasoning) dalam setiap menjawab soal belum berkembang secara maksimal (Anisah et. al., 2011). Berdasarkan hasil penelitian dapat diketahui bahwa tingkat literasi statistik siswa tergolong dalam kategori sangat rendah dimana persentasenya adalah 48,6\% (Thirafi, 2017). Sebagian besar siswa mengalami kesulitan dalam mengerjakan soal statistika yang diberikan. Demikian pula halnya ketersediaan soal-soal kemampuan literasi matematis materi statistika di Sekolah Menengah Pertama masih sangat minim. Penelitian ini, diperkuat oleh penelitian lain dengan topik penelitian yang sama bahwa pencapaian prestasi matematika siswa di Indonesia masih rendah, hal ini terlihat dari hasil studi PISA pada tahun 2015 (Junika et. al., 2020). Salah satu faktornya dikarenakan siswa kurang terlatih menyelesaikan soal berkarakteristik seperti soal PISA. Sehingga dibutuhkan suatu pengembangan soal yang mampu memberi ruang pada siswa untuk melatih kemampuan literasi matematis yang salah satunya yaitu kemampuan literasi statistika. Tujuan penelitian adalah mengembangkan soal statistika model PISA yang berkualitas untuk melatih kemampuan literasi statistika siswa. Penelitian menghasilkan tujuh (7) butir soal yang berkualitas yaitu valid, reliabel, daya pembeda dan tingkat kesukaran yang baik. Namun penelitian ini terdapat beberapa kekurangan yang salah satunya tidak semua soal uji coba berkualitas baik yang artinya soal dalam penelitian ini tidak semua anak bisa mengerjakan atau keterbacaan soal anak belum baik. Soal belum dapat dikatakan praktis. Sehingga perlu pembaharuan penelitian yang tidak hanya soal yang valid tetapi juga praktis.

Salah satu upaya yang harus dilakukan untuk meningkatkan kemampuan literasi matematis siswa adalah dengan cara membiasakan dan mengerjakan soal berkarakteristik PISA. Sehingga tujuan dari 
penelitian ini yaitu mengembangkan dan menghasilkan soal-soal yang dapat melatih kemampuan literasi matematis yang valid dan praktis.

\section{METODE}

Jenis penelitian yang digunakan adalah penelitian pengembangan (Development Research) (Nieveen, 2007). Menggunakan model Tessmer (1998) yang dimodifikasi (Zulkardi, 2006). Penelitian pengembangan ini ditujukan untuk menghasilkan produk pendidikan.

Tujuan penelitian pengembangan yaitu untuk menghasilkan dan memperbaiki produk berupa soalsoal melalui proses pengembangan. Penelitian ini mengembangkan soal-soal matematika materi statistika untuk kemampuan literasi matematis siswa level 3 Sekolah Menengah Pertama (SMP) kelas VIII. Berikut Diagram Tahap model Tessmer (1998) yang dimodifikasi (Zulkardi, 2006) disajikan dalam Gambar 1.

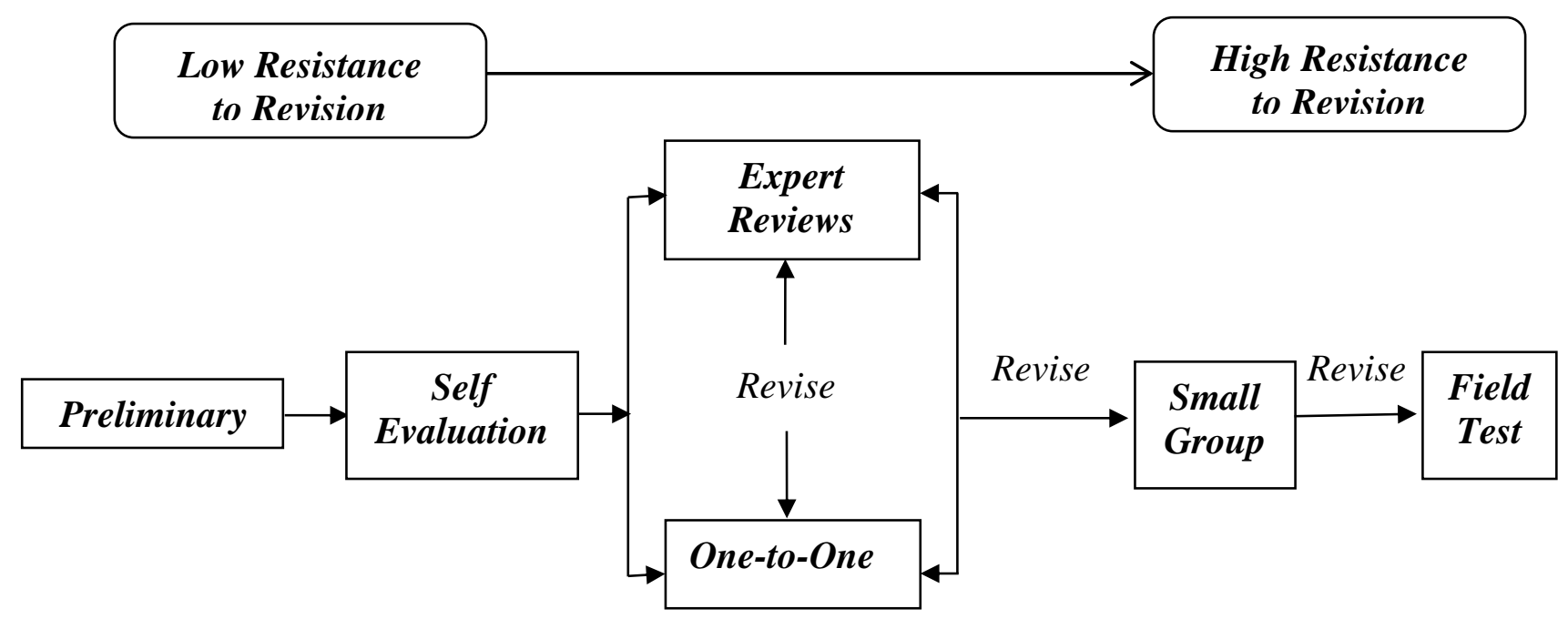

Gambar 1. Alur Desain Tessmer Dimodifikasi

Teknik pengumpulan data dalam penelitian ini antara lain sebagai berikut: 1) metode pengumpulan data, yaitu wawancara; 2) instrumen pengumpulan data yaitu dokumen, lembar validasi soal, lembar komentar atau saran, dan prototype. Prototype yang disusun merupakan prototype berbentuk soal essay materi statistika yang telah dibuat dan dinilai sesuai konten, konstruk dan bahasa. Pada tahap ini dilakukan satu kali uji coba yaitu dilakukan diakhir pembelajaran. Teknik analisis data yang digunakan pada penelitian adalah analisis kualitatif hal ini dikarenakan keadaan untuk melakukan penelitian masih sulit untuk mencapai analisis secara kuantitatif. Selain sekolah belum sepenuhnya buka, keadaan covid-19 di Indonesia masih naik turun. Teknik analisis data yang digunakan pada penelitian melalui Expert Review dan One-toOne. Expert Review, hasil validasi pada tahap ini yang berdasarkan konten, konstruk, dan bahasa dianalisis secara kualitatif sebagai bahan untuk merevisi prototype pertama. Sedangkan One-to-One, hasil komentar dari siswa pada tahap ini dianalisis secara kualitatif sebagai pertimbangan keterbacaan dan kejelasan soal yang telah dibuat. Hasil revisi dari One-to-One terhadap prototype dianalisis secara kualitatif sebagai bahan untuk merevisi prototype kedua.

\section{HASIL}

Penelitian yang dilakukan peneliti menghasilkan 10 soal kemampuan literasi matematis level 3 yang telah divalidasi oleh para ahli, serta diujicobakan kepada siswa. Langkah-langkah yang digunakan untuk mengembangkan soal-soal kemampaun literasi level 3 materi statistika adalah 


\section{Preliminary}

Persiapan yang dilakukan adalah melihat masalah yang ada. Masalah yang ditemukan adalah kurangnya referensi soal-soal berbasis kemampuan literasi matematis materi statistika. Soal-soal ini diperlukan untuk melatih dan mengetahui kemampuan literasi matematis siswa. Kemudian menentukan tempat yang dijadikan sebagai tempat penelitian di SMP N 58 Bengkulu Utara. Selanjutnya menghubungi kepala sekolah dan guru mata pelajaran matematika untuk meminta izin bahwa akan melakukan penelitian di sekolah tersebut dan mengatur jadwal penelitian dan prosedur kerja sama dengan guru mata pelajaran matematika kelas VIII. Selain itu juga dilakukan analisis sebagai acuan untuk mengembangkan soal kemampuan literasi. Hasil analisis peneliti yang dilakukan meliputi:

a. Analisis Kurikulum

Kurikulum yang digunakan di SMP N 58 Bengkulu Utara adalah Kurikulum 2013. Salah satu tujuan pembelajaran pada Kurikulum 2013 adalah mengajarkan kepada siswa menggunakan kemampuan literasi matematis.

b. Analisis siswa

Hasil dari analisis siswa bahwa siswa kelas VIII SMP N 58 Bengkulu Utara telah mampu mengkomunikasikan ide atau gagasan matematisnya menggunakan simbol, diagram, tabel, alat media lainnya serta mampu menyajikan suatu masalah dengan bahasa matematis.

c. Analisis materi.

Analisis terhadap materi yang digunakan pada saat penelitian yaitu materi statistika yang merupakan salah satu materi pokok mata pelajaran matematika yang dipelajari siswa SMP kelas VIII pada semester 2. Sebelum mempelajari materi statistika, siswa sudah mempelajari penyajian data dari jenis data, tabel, diagram dan grafik di kelas VII. Sehingga ketika dilakukan penelitian siswa sudah mempelajari materi tersebut. Pada materi statistika belum menggunakan soal kemampuan literasi untuk meningkatkan kemampuan literasi siswa. Dari 10 soal yang valid memiliki materi pembelajaran yang sama dengan KD yang sama. Soal no. 1,9 dan 10 yaitu dengan sub materi mengambil keputusan berdasarkan analisis data, no. 2 sub materi modus, no. 3 sub materi rata-rata, no. 4 sub materi median dan modus, no. 5-8 membuat prediksi berdasarkan analisis data dengan KD menganalisis data, menyajikan dan menyelesaikan masalah yang berkaitan dengan distribusi data, nilai rata-rata, median, modus, dan sebaran data untuk mengambil kesimpulan, membuat keputusan, dan membuat predisksi selanjutnya peneliti mendesain soal berdasarkan acuan dari analisis kurikulum, materi, dan siswa.

\section{Self Evaluation}

Soal yang telah didesain berdasarkan materi dan indikator menghasilkan soal berjumlah 10 soal. Kemudian dinilai sendiri secara konten, konstruk, dan bahasa. Hal ini dilakukan sebelum divalidasi oleh validator. Hasil dari tahap ini di disebut prototype pertama.

\section{Expert Reviews}

Pada tahap ini, hasil soal yang telah didesain untuk kemampuan literasi matematis divalidasi oleh tiga orang validator, yaitu dua orang dosen Pendidikan Matematika Universitas Muhammadiyah Bengkulu dan satu orang guru matematika kelas VIII SMP Negeri 58 Bengkulu Utara. Soal yang didesain divalidasi berdasarkan konten, konstruk, dan bahasa. Validasi soal ini merupakan analisis secara kualitatif terhadap butir soal. Hasil telaah validator disampaikan secara lisan dan tertulis pada lembar komentar dan saran validator. Komentar dan saran inilah yang digunakan untuk merevisi prototype 1. Pada Gambar 2. diberikan display data terkait komentar dan saran dari validator. 


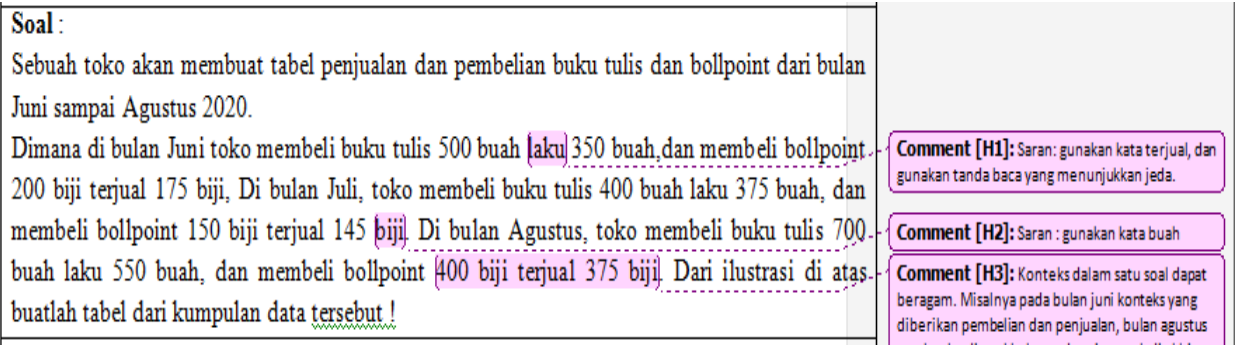

Gambar 2. Komentar/Saran Validator Terkait Penggunaan Tata Bahasa

Gambar 2. memberikan informasi terkait adanya saran dan komentar yang tidak hanya pada segi bahasa. Komentar dari segi bahasa menunjukkan agar menyesuaikan penggunaan pemilihan kata yang tepat, penggunaan tanda baca yang tepat. Di luar dari segi bahasa, komentar terkait isi yang mengikuti kaidah konsep matematika pun disampaikan oleh validator.

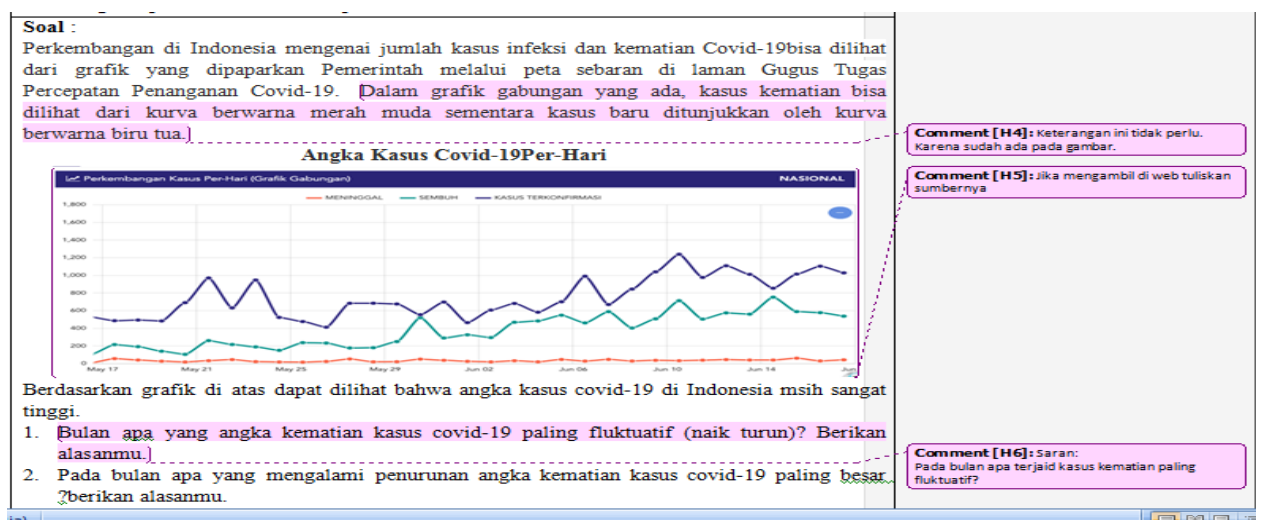

Gambar 3. Komentar/Saran Validator Terkait Tinjauan Literasi

Saran dan komentar yang tersaji dalam Gambar 3., menunjukkan validator mengomentari terkait dari tinjauan literasi. Menyajikan suatu persoalan dengan efektif. Kaidah dalam pengambilan informasi dari sumber lain juga perlu diperhatikan. Agar konteks permasalahan dapat dipahami dengan baik, validator pun memberikan komentar terkait penyajian/pengemasan kalimat tanya yang baik.

4. One-to-One

Desain soal yang telah valid berdasarkan validasi para validatordengan menghasilkan 10 soal yang valid, selanjutnya soal diberikan kepada 3 orang siswa SMP kelas VIII yang memiliki kemampuan berbeda dengan cara berhadapan satu lawan satu. Pada uji coba satu lawan satu, siswa diminta membaca, memahami maksud dan tujuan, serta peneliti mencatat komentar/saran siswa terhadap soal yang diberikan. Pada tahap ini didapatkan hasil soal yang sudah divalidasi oleh para validator secara keseluruhan dapat terbaca oleh siswa.

\section{Small Group}

Kemudian prototype II diujicobakan juga pada small group, subjek uji coba yaitu 30 orang siswa dengan memiliki kemampuan heterogen. Tujuan dari small group yaitu untuk mencari kepraktisan soal.

Hasil dan teknik pengumpulan data dalam penelitian diuraikan atas metode pengumpulan data dan instrumen pengumpulan data. Metode pengumpulan data yang dilakukan melalui wawancara. Wawancara merupakan salah satu metode pengumpulan data yang dilakukan di tahap one-to-one. Pada tahap ini wawancara dilakukan untuk mengetahui keterbacaan soal siswa. Pada saat wawancara siswa hanya diminta membaca, memahami maksud dan tujuan, serta peneliti mencatat komentar/saran siswa terhadap soal yang diberikan. Dalam wawancara tersebut hanya dibutuhkan tiga orang siswa yang memiliki 
kemampuan heterogen. Wawancara dilakukan satu persatu kepada peneliti. Adapun komentar/saran siswa terhadap soal yang diujicobakan ditampilkan dalam Tabel 1.

Tabel 1. Komentar Siswa pada Tahap One-to-One terhadap Soal

\begin{tabular}{|c|c|c|c|}
\hline \multirow[t]{2}{*}{ No } & \multicolumn{3}{|c|}{ Komentar/Saran Siswa terhadap Soal } \\
\hline & S1 & S2 & S3 \\
\hline 1 & Soal dapat dipahami & Soal dapat dipahami & $\begin{array}{l}\text { Soal dapat dipahami tapi masih } \\
\text { bingung cara mengerjakannya }\end{array}$ \\
\hline 2 & Soal dapat dipahami & $\begin{array}{l}\text { Soal cukup dapat dipahami } \\
\text { tetapi perlu dijelaskan } \\
\text { kembali }\end{array}$ & Soal dapat dipahami \\
\hline 3 & Soal dapat dipahami & $\begin{array}{l}\text { Soal sudah jelas, tetapi cara } \\
\text { mengerjakannya tidak tau } \\
\text { darimana terlebih dahulu }\end{array}$ & $\begin{array}{l}\text { Soal dapat dipahami, tetapi } \\
\text { perlu dijelaskan kembali }\end{array}$ \\
\hline 4 & Soal dapat dipahami & Soal dapat dipahami & $\begin{array}{l}\text { Soal dapat dipahami, tetapi } \\
\text { ilustrasi pada gambar kurang } \\
\text { jelas. }\end{array}$ \\
\hline 5 & $\begin{array}{l}\text { Soal dapat dipahami, } \\
\text { namun ilustrasi gambar } \\
\text { perlu diperjelas kembali }\end{array}$ & Soal dapat dipahami & Soal cukup jelas \\
\hline 6 & $\begin{array}{l}\text { Soal dapat dipahami tapi } \\
\text { cara menyelesaikannya } \\
\text { masih bingung }\end{array}$ & $\begin{array}{l}\text { Soal dapat dipahami, tetapi } \\
\text { perlu dijelaskan kembali dan } \\
\text { harus teliti }\end{array}$ & $\begin{array}{l}\text { Soal kurang dipahami, ketika } \\
\text { diberi penjelasan sedikit siswa } \\
\text { memahami maksud soal, dan } \\
\text { siswa masih bingung cara } \\
\text { mengerjakannya. }\end{array}$ \\
\hline 7 & Soal dapat dipahami & Soal dapat dipahami & $\begin{array}{l}\text { Soal cukup dapat dipahami, } \\
\text { tetapi siswa perlu diberi } \\
\text { penjelasan dari ilustrasi } \\
\text { pertanyaan soal }\end{array}$ \\
\hline 8 & Soal cukup dipahami & $\begin{array}{l}\text { Soal dapat dipahami, tapi } \\
\text { masih bingung cara } \\
\text { mengerjakannya. }\end{array}$ & Soal dapat dipahami \\
\hline 9 & Soal dapat dipahami & Soal dapat dipahami & Soal dapat dipahami \\
\hline 10 & $\begin{array}{l}\text { Soal dapat dipahami, } \\
\text { tetapi bingung cara } \\
\text { mengerjakannya }\end{array}$ & Soal jelas & $\begin{array}{l}\text { Soal dapat dipahami tetapi cara } \\
\text { menyelesaikannya masih } \\
\text { bingung. }\end{array}$ \\
\hline
\end{tabular}

Sumber: diolah dari data penelitian, 2021

Keterangan: $\mathrm{S} 1=$ Siswa berkemampuan tinggi

S2 = Siswa berkemampuan sedang

S3 = Siswa berkemampuan rendah

Dalam Tabel 1. terlihat bahwa secara garis besar siswa dapat memahami soal-soal yang diberikan. Pada siswa 1, soal no. 1, 2, 3, 4, 7, 8, 9 siswa sudah dapat memahami soal dengan baik, sudah dapat memahami maksud dan tujuan dari soal tersebut. Untuk soal no. 5, siswa 1 masih perlu dijelaskan kembali ilustrasi gambar yang ada pada no. 5. Dan untuk soal no. 6 dan 10 siswa 1 masih bingung atau belum mengerti cara mengerjakan soal tersebut. Selanjutnya keterbacaan soal pada siswa 2, soal no. 1, 4, 5, 7, 9, dan 10 siswa sudah dapat memahami maksud dan tujuan dari soal dengan baik. Soal no. 2, 3, 6, dan 8 siswa 
2 masih perlu dijelaskan kembali maksud soal dan belum paham alur cara mengerjakan soal tersebut. Kemudian siswa 3 sudah dapat memahami soal dengan baik pada no. 2, 5, 8, 9 dan siswa 3 masih perlu dijelaskan kembali maksud soal, ilustrasi gambar dan belum paham alur cara mengerjakan soal pada no. 1, $3,4,6,7$, dan 10. Berdasarkan hasil wawancara yang telah dilakukan bahwa keterbacaan soal siswa pada tahap one-to-one sudah baik.

Sedangkan instrument pengumpulan data meliputi dokumen, lembar validasi soal, lembar komentar dan saran, serta prototype. Dokumen yang dimaksud adalah dokumen yang berisi tentang kurikulum yang sedang berlaku di sekolah dan pengetahuan siswa. Hasil yang didapat bahwa kurikulum yang digunakan di sekolah adalah Kurikulum 2013 dan pengetahuan siswa tentang materi statistika dapat dipahami. Dokumen ini dikumpulkan untuk dijadikan acuan dalam mendesain soal-soal untuk kemampuan literasi matematis siswa.

Instrumen selanjutnya, digunakan lembar validasi soal. Di bagian instrumen ini, digunakan untuk mengukur atau untuk mengetahui kevalitan soal yang akan ditujukan ke validator yaitu dosen dan guru mata pelajaran matematika SMP kelas VIII. Instrumen ini digunakan pada tahap expert reviews untuk mendapatkan data validasi berdasarkan konten, konstruk, dan bahasa. Berikut salah satu hasil lembar validasi dari salah satu validator yang bersifat kualitatif disajikan dalam Gambar 4.
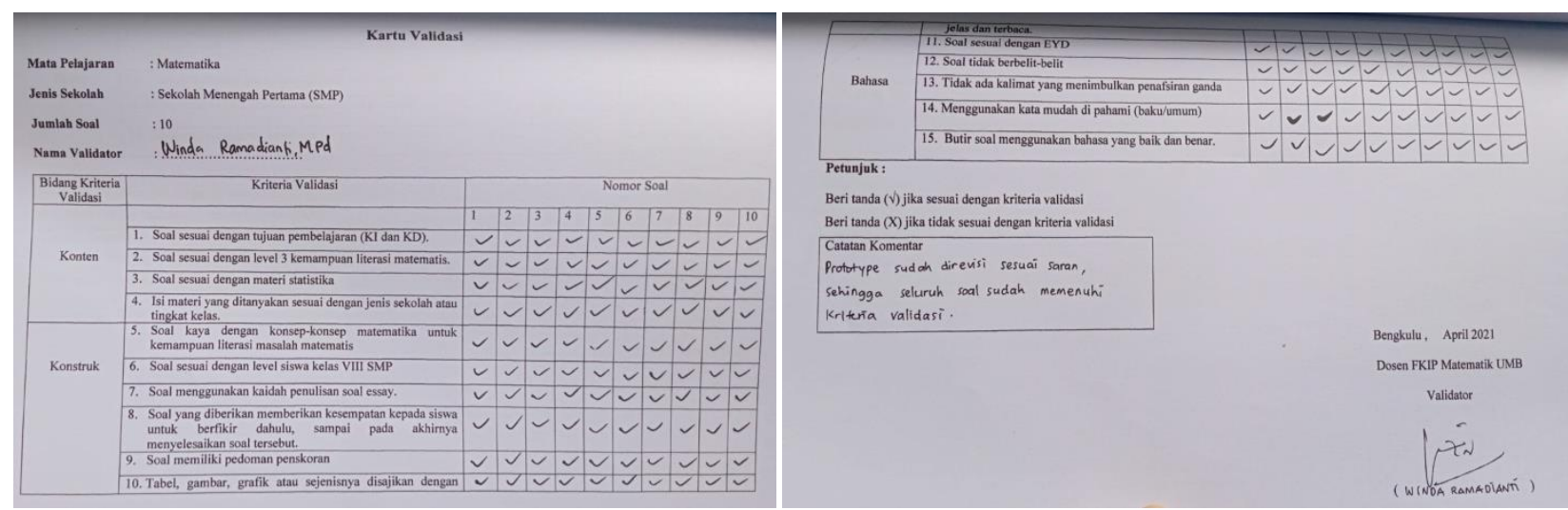

\section{Gambar 4. Lembar Validasi}

Lembar komentar atau saran, instrumen ini digunakan pada tahap expert reviews dan One-to-One untuk mendapatkan data terhadap pendapat soal yang telah didesain dan keterbacaan soal hasil pada instrumen ini sudah ada pada tahap expert reviews dan pada saat wawancara.

Instrumen terakhir prototype, merupakan soal-soal yang diujicobakan kepada siswa di tahap small group dimana soal-soal tersebut sudah dinyatakan valid oleh validator. Gambar 5. berikut salah satu prototype yang sudah valid.

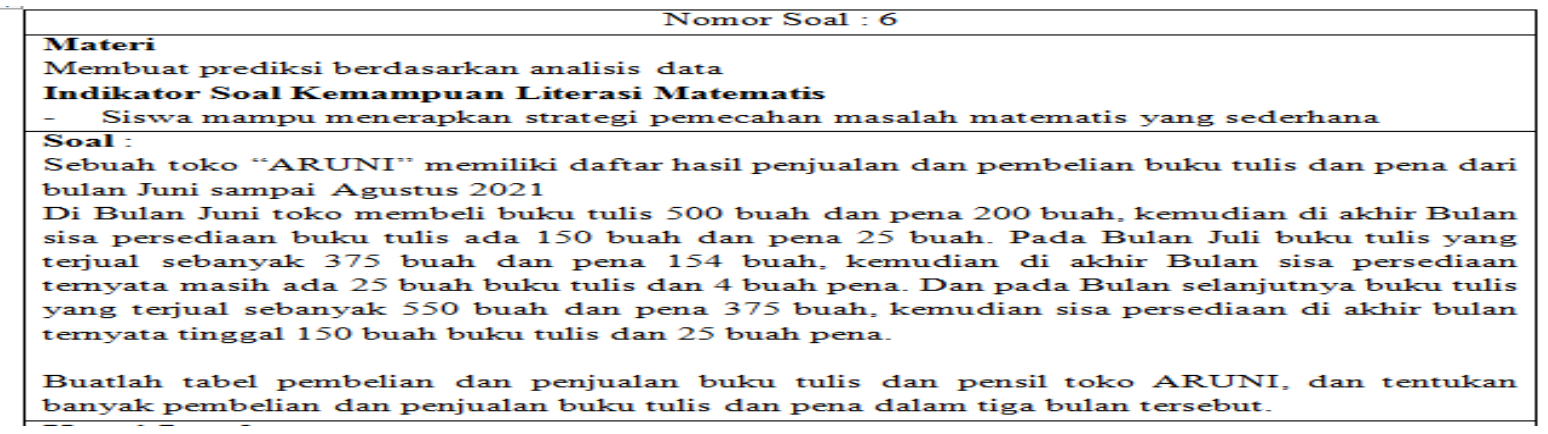

\section{Gambar 5. Prototype yang Sudah Valid}


Hasil prototype valid sudah diujicobakan kepada siswa di tahap small group. Hasil dari tahap ini didapatkan dari jawaban. Siswa berkemampuan tinggi dan siswa berkemampuan sedang sudah dapat menyelesaikan soal sesuai dengan indikator yang diminta pada setiap soal, sedangkan siswa berkemampuan rendah sudah dapat menyelesaikan soal walaupun belum semua indikator dapat terpenuhi. Secara umum siswa sudah dapat memberikan ide yang merupakan hasil dari pemikirannya sendiri. Hal ini berarti dapat dikatakan bahwa siswa memiliki kemampuan literasi matematis dan soal dapat dikatakan praktis karena bisa digunakan dengan baik oleh siswa.

\section{PEMBAHASAN}

Penelitian pengembangan soal yang telah dilakukan menggunakan model Tessmer (1998) yang di modifikasi (Zulkardi, 2006). Pengembangan soal ini telah melalui serangkaian proses pengembangan mulai dari tahap preliminary, self evaluation, experts review, one-to-one small group dan field test. Namun pada penelitian pengembangan ini hanya dibatasi sampai tahap small group sehingga menghasilkan sebuah produk berupa soal kemampuan literasi matematis pada materi statistika untuk siswa SMP Kelas VIII yang valid dan praktis. Dalam proses pengembangan soal ini evaluasi selalu dilakukan pada kelima tahap pengembangan. Setelah dilakukan evaluasi pada tahap preliminary tahap dimana kita melakukan persiapan sebelum kita melakukan uji coba soal kepada siswa terutama menganalisis kurikulum, siswa, dan materi selanjutnya adalah tahap design atau perancangan. Kemudian self evaluation. Tahap ini merupakan tahap penilaian sendiri terhadap soal yang sudah peneliti design sebelum di validasi oleh para validator. Selanjutnya tahap experts review. Tahap ini memvalidasi soal oleh para validator hingga soal dapat dikatakan valid.

Valid terlihat dari hasil validasi oleh ketiga validator, dimana validator menyatakan soal sudah baik berdasarkan konten, konstruk, dan bahasa (Lewy, 2013). Valid secara konten, soal telah sesuai dengan tujuan pembelajaran (KI dan KD), soal sudah sesuai dengan level 3 kemampuan literasi matematis dari 6 level kemampuan literasi matematika siswa. Hal ini diketahui bahwa penilaian PISA siswa di SMP berada pada level 1 atau 2 dalam kemampuan literasi matematis, sehingga perlu dilakukan peningkatan level tahap pertahap pada siswa SMP, soal telah sesuai dengan materi dan isi materi yang ditanyakan sesuai dengan jenis sekolah atau tingkat kelas (OECD, 2018). Valid secara konstruk, soal sudah sesuai dengan konsepkonsep matematika untuk kemampuan literasi masalah matematis, soal sudah sesuai dengan level siswa kelas VIII SMP, soal yang diberikan memberikan kesempatan kepada siswa untuk berfikir dahulu, sampai pada akhirnya menyelesaikan soal tersebut, soal telah memiliki pedoman penskoran, dan ada petunjuk jelas tentang cara mengerjakan soal, tabel, gambar, grafik atau sejenisnya disajikan dengan jelas dan terbaca. Valid secara bahasa yaitu soal sesuai dengan Pedoman Umum Ejaan Bahasa Indonesia (PUEBI), menggunaaan kata mudah dipahami (baku/umum) serta tidak mengandung penafsiran ganda (ambigu). Selanjutrnya tahap one-to-one, tujuan di tahap ini untuk melihat keterbacaan tiga orang siswa yang memiliki kemampuan heterogen terhadap soal yang sudah dinyatakan valid dan sudah di validasi oleh validator. Dari proses tahap ini didapatkan hasil secara keseluruhan dapat terbaca oleh siswa. Selanjutnya tahap terakhir adalah tahap small group. Tahap ini merupakan tahap ujicoba soal kepada sampel yang berjumlah 30 orang siswa. Uji coba tahap ini untuk melihat kepraktisan soal. Ke-30 siswa tersebut diminta mengerjakan soal prototype II yang diberikan. Kemudian peneliti mengamati siswa apabila siswa mengalami kendala dalam mengerjakan soal. Sehingga dari hasil uji coba tahap ini sebagian besar soal-soal yang dikembangkan telah praktis untuk digunakan.

Berdasarkan hasil jawaban siswa yang diperoleh bahwa semua siswa melibatkan Kemampuan Dasar Matematika (KDM) dalam menjawab soal (Putra, et. al., 2016). Selain itu berdasarkan komentar siswa 
bahwa siswa tidak terbiasa mengerjakan soal-soal model PISA yang sesuai dengan teori bahwa rendahnya hasil PISA siswa Indonesia disebabkan oleh lemahnya kemampuan pemecahan masalah soal non-routine atau level tinggi, sistem evaluasi di Indonesia yang masih menggunakan soal level rendah, dan siswa terbiasa memperoleh dan menggunakan pengetahuan matematika formal di kelas (Stacey, 2010; Wu, 2011; Novita, et. al., 2012; Mulyatna, et. al., 2021). Dengan demikian, pengembangan soal sebagai instrumen untuk mengukur kemampuan literasi siswa menjadi penting, dan telah dilakukan dalam penelitian ini dengan hasil yang valid.

Berdasarkan pemaparan peneliti lakukan serta hasil penelitian yang selaras sebelumnya dapat di yakinkan bahwa pengembangan soal yang telah dibuat dapat digunakan untuk melatih kemampuan literasi matematis siswa untuk tingkat Sekolah Menengah Pertama kelas VIII, selain itu pentingnya soal kemampuan literasi sebagai bahan untuk membiasakan siswa mengerjakan soal yang berkarakteristik PISA agar kemampuan siswa dapat sebanding dengan kemampuan siswa di negara lain. Secara umum hasil dan pembahasan penelitian ini, melengkapi hasil penelitian dilakukan oleh (Sasongko, et. al., 2016). Penelitian yang bertujuan untuk mendeskripsikan proses dan hasil pengembangan berupa konversi level kemampuan literasi matematika, kisi-kisi soal model PISA, paket soal model PISA. Ketiga tahapan uji coba adalah oneto-one, group, dan field test. Ketiga tahapan ini menghasilkan koefisien validitas paket soal A dengan paket soal B yang berbeda-beda hasilnya, reliabilitas paket soal A sebesar 0,87247 dengan interpretasi sangat tinggi sedangkan paket B sebesar 0,78634 dengan interpretasi tinggi kemudian tingkat kesukaran pada paket A dan paket soal B menghasilkan jumlah hasil yang berbeda. Dan daya pembeda paket soal A terdiri dari $8,33 \%$ jelek, $16,67 \%$ cukup baik, $25 \%$ baik dan 50\% sangat baik, sedangkan paket soal B terdiri dari 16,67\% jelek, 8,33\% cukup baik, 33,33\% baik dan 41,67\% sangat baik; sehingga dapat disimpulkan bahwa level literasi matematika seluruh siswa yang diuji adalah 50\% siswa berlevel di bawah 1,7,14\% siswa berlevel 1, 9,52\% siswa berlevel 2, 16,67\% siswa berlevel 3,2,38\% siswa berlevel 4, 4,76\% siswa berlevel 5, dan 9,52\% siswa berlevel 6.

Penelitian lain juga melengkapi hasil dan pembahasan penelitian ini bahwa pencapaian prestasi matematika siswa di Indonesia masih rendah, terlihat dari hasil studi PISA pada tahun 2015 (Junika, et. al., 2020). Salah satu faktornya dikarenakan siswa kurang terlatih menyelesaikan soal berkarakteristik seperti soal PISA. Sehingga dibutuhkan suatu pengembangan soal yang mampu memberi ruang pada siswa untuk melatih kemampuan literasi matematis yang salah satunya yaitu kemampuan literasi statistika. Tujuan penelitian ini adalah mengembangkan soal statistika model PISA yang berkualitas untuk melatih kemampuan literasi statistika siswa. Instrumen pengumpulan data yang digunakan yaitu instrumen untuk mengukur kevalidan soal dan lembar hasil uji coba. Penelitian ini menghasilkan 7 (tujuh) butir soal yang berkualitas yaitu valid, reliabel, daya pembeda dan tingkat kesukaran yang baik.

Dari kedua penelitian tersebut dapat disimpulkan bahwa dari penelitian sebelumnya hanya mengembangkan soal dengan menghasilkan soal yang valid, reliabel, daya pembeda dan tingkat kesukaran yang baik. Tetapi dalam penelitian ini, dilakukan penelitian pada uji kepraktisan dengan menggunakan teknik analisis secara kualitatif. Tidak hanya sangat valid, reliabel, daya pembeda dan tingkat kesukaran yang baik tetapi juga praktis digunakan untuk kalangan siswa SMP sebagai bahan media pembelajaran matematika

\section{SIMPULAN}

Berdasarkan hasil dan pembahasan dapat disimpulkan bahwa suatu produk yaitu 10 soal essai kemampuan literasi matematis level 3 SMP kelas VIII materi statistika yang valid dan praktis. Hasil pengembangan soal kemampuan literasi matematis pada materi statistika untuk siswa SMP kelas VIII melalui penilaian validator pada tahap expert review berdasarkan konten, konstruk dan bahasa didapatkan 
10 soal yang valid. Hasil pengembangan soal kemampuan literasi matematis pada materi statistika untuk siswa SMP kelas VIII melalui keterbacaan tiga orang siswa bahwa siswa dapat mengerti, memahami maksud dan tujuan dari soal didapatkan 10 soal yang praktis.

Saran yang peneliti berikan berdasarkan hasil dan simpulan penelitian, yaitu: 1) pengembangan soal kemampuan literasi matematis siswa kelas VIII SMP yang dikembangkan hanya sebatas materi statistika, sehingga perlu dikembangkan lebih luas lagi; 2) proses pengembangan soal kemampuan literasi matematis siswa kelas VIII SMP ini hanya dilakukan sampai pada tahap small group, sehingga diharapkan adanya tindakan untuk melanjutkan pada uji coba field test atau uji coba luas.

\section{DAFTAR RUJUKAN}

Abdurrahman, M. (2003). Pendidikan Bagi Anak Berkesulitan Belajar. Jakarta: Rineka Cipta. Abidin, Y., Mulyati, T., \& Yunansah, H. (2018). Pembelajaran Literasi. Jakarta: Bumi Aksara.

Anisah, Zulkardi, \& Darmawijoyo. (2011). Pengembangan Soal Matematika Model PISA pada Konten Quantity untuk Mengukur Kemampuan Penalaran Matematis Siswa Sekolah Menengah Pertama. Jurnal Pendidikan Matematika, 5(1). https://doi.org/https://doi.org/10.22342/jpm.5.1.333.

Asmara, A., \& Risnanosanti. (2019). Literasi Matematika Siswa SMP Melalui Model Problem Based Learning. Jurnal MATH-UMB.EDU, 6(3), 1-5. https://doi.org/https://doi.org/10.36085/mathumb.edu.v6i3.498

Asmara, A., \& Sari, D. J. (2021). Pengembangan Soal Aritmetika Sosial Berbasis Literasi Matematis Siswa SMP. Jurnal Cendekia: Jurnal Pendidikan Matematika, 5(3), 2950-2961. https://doi.org/https://doi.org/10.31004/cendekia.v5i3.982

Habibi, \& Suparman. (2020). Literasi Matematika dalam Menyambut PISA 2021 Berdasarkan Kecakapan Abad 21. JKPM (Jurnal Kajian Pendidikan Matematika), 6(1), 57-64. https://doi.org/http://dx.doi.org/10.30998/jkpm.v6i1.8177

Hobri. (2008). Model-model Pembelajaran Inovatif. Jember: Universitas Jember.

Junika, N., Izzati, N., \& Tambunan, R. (2020). Pengembangan Soal Statistika Model PISA untuk Melatih Kemampuan Literasi Statistika Siswa. Mosharafa: Jurnal Pendidikan Matematika, 9(3), 499-510. https://doi.org/https://doi.org/10.31980/mosharafa.v9i3.615

Kemdikbud. (2011). Survei International PISA. Retrieved from http:litbang.kemdikbud.go.id/index.php/survei-internasional-pisa.

Khanifah, Sutrisno, \& Purwosetiyono, F. D. (2019). Literasi Matematika Tahap Merumuskan Masalah Secara Matematis Siswa kemampuan Tinggi dalam Memecahkan Masalah Matematika Kelas VIII. JKPM (Jurnal Kajian Pendidikan Matematika), $37-48$. https://doi.org/http://dx.doi.org/10.30998/jkpm.v5i1.4544

Khotimah. (2018). Meningkatkan Kemampuan Literasi Matematis dengan Pendekatan Metacognitive Guidance Berbantuan Geogebra. GAUSS: Jurnal Pendidikan Matematika, 1(1), 53-65. https://doi.org/https://doi.org/10.30656/gauss.v1i1.636

Kuswidi, I. (2015). Brain-Based Learning untuk Meningkatkan Literasi Matematis Siswa. Al-Jabar Jurnal Pendidikan Matematika, 6(2), 195-202. https://doi.org/https://doi.org/10.24042/ajpm.v6i2.49

Lewy, L. (2013). Pengembangan Soal Untuk Mengukur Kemampuan Berpikir Tingkat Tinggi Pokok Bahasan Barisan Dan Deret Bilangan di Kelas IX Akselerasi SMP Xaverius Maria Palembang. Jurnal Pendidikan Matematika, 5(1), 58-73. https://doi.org/10.22342/jpm.5.1.821.

Lutfianto, M. (2013). Unfinished Student Answer in PISA Mathematics Contextual Problem. The First South East Asia Design/ Development Research (SEA-DR) International Conference, 188-193.

Mahfudhoh, R., Susanto, \& Trapsilasiwi, D. (2017). Pengembangan Soal Pelevelan Literasi Matematika 
Konteks Personal untuk Siswa Kelas VIII SMP. KadikmA, 8(3), 58-67. https://doi.org/https://doi.org/10.19184/kdma.v8i3.6900

Maryanti, E. (2012). Peningkatan Literasi Matematis Siswa melalui Pendekatan Metacognitive Guidance.

Disertasi: Universitas Pendidikan Indonesia.

Mulyatna, F., Imswatama, A., \& Rahmawati, N. D. (2021). Design Ethnic-Math HOTS: Mathematics Higher Order Thinking Skill Questions Based On Culture and Local Wisdom. Malikussaleh Journal of Mathematics Learning (MJML), 4(1), 48. https://doi.org/10.29103/mjml.v4i1.3059

Nieveen, N. (2007). An Introduction Design Research: Formative Evaluation in Educational Design Research. In Tj. Plomp \& N. Nieveen (Eds.), Proceedings of the seminar conducted at the East China Normal University, Shanghai (PR China) (pp. 89-101). Enschede: SLO.

Novita, R., Zulkardi, \& Hartono, Y. (2012). Exploring Primary Student's Problem-Solving Ability by Doing Tasks Like PISA's Question. Journal on Mathematics Education (JME), 3(2), 133-150. https://doi.org/https://doi.org/10.22342/jme.3.2.571.133-150

OECD. (2018). What 15-year-old students in Indonesia know and can do. Programme for International Student Assessment (PISA) Result from PISA 2018, 1-10.

OECD. (2019a). PISA for Development Assessment and Analytical Framework. OECD Publishing.

OECD. (2019b). Programme For InternationalStudent Assessment (PISA) 2018 Result in Focus-What 15years-olds know and they can do with what they know. OECD Publishing.

Putra, Y. Y., Zulkardi, \& Hartono, Y. (2016). Pengembangan Soal Matematika Model PISA Konten Bilangan untuk Mengetahui Kemampuan Literasi Matematika Siswa. Jurnal Elemen, 2(1), 14-16. https://doi.org/https://doi.org/10.29408/jel.v2i1.175

Rodiawati, H., \& Komarudin, K. (2018). Pengembangan E-Learning Melalui Modul Interaktif Berbasis Learning Content Development System. Jurnal Tatsqif, 16(2), 172-185. https://doi.org/https://doi.org/10.20414/jtq.v16i2.190

Sasongko, T. P. M., Dafif, \& Ervin Oktavianingtyas. (2016). Pengembangan Paket Soal Model PISA Konten Space and Shape untuk Mengetahui Level Literasi Matematis Siswa SMP. Jurnal Edukasi, 3(1), 27 32. https://doi.org/https://doi.org/10.19184/jukasi.v3i1.4317

Shiel, G., Perkins, R., Close, S., \& Oldham, E. (2007). PISA Mathematics: a teacher's guide. Retrieved from https://www.researchgate.net/publication/265011126_PISA_Mathematics_A_Teacher's_Guide.

Stacey, K. (2010). Mathematical and Scientific Literacy Around The World. Journal of Science and Mathematics Education in Southeast Asia, 33(1), 1-16.

Stacey, K. (2011). The PISA view of mathematical literacy in Indonesia. Journal on Mathematics Education, 2(2), 95-126. https://doi.org/10.22342/jme.2.2.746.95-126

Thirafi, G. (2017). Analisis tingkat literasi statistik pada siswa kelas IX MTs. Al-aziziyah Putra Gunung Sari tahun pelajaran 2016/2017. Artikel Skripsi tersedia di Docplayer Universitas Mataram.

Wiratomo, Y., \& Mulyatna, F. (2020). Use of Learning Management Systems in Mathematics Learning during a Pandemic. Journal of Mathematical Pedagogy (JoMP), 1(2), 62-71. https://doi.org/https://doi.org/10.26740/jomp.v1n2.p\%25p

$\mathrm{Wu}, \mathrm{M}$. (2011). Using PISA and TIMSS Mathematics Assessments to Identify Relative Streng ths of Students in Western and Asian. Journal of Research in Education Sciences, 56(1), 67-89.

Zulkardi. (2006). Formative Evaluation: What, Why, When, and How. Retrieved from http://www.oocities.org/zulkardi/books.html. 